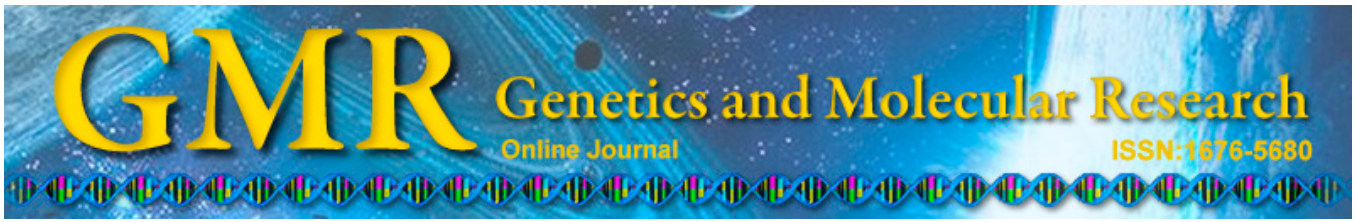

\title{
Development of a novel set of microsatellite markers for Lippia alba (Verbenaceae)
}

\author{
D.S. Rocha ${ }^{1}$, C.P. Santos ${ }^{2}$, M.M. Bajay ${ }^{3}$, J.B. Campos ${ }^{1}$, A.F. Blank ${ }^{2}$, \\ J.B. Pinheiro ${ }^{3}$ and M.I. Zucchi ${ }^{1}$ \\ ${ }^{1}$ Laboratório de Biologia Molecular, \\ Agência Paulista de Tecnologia dos Agronegócios, Piracicaba, SP, Brasil \\ ${ }^{2}$ Laboratório de Cultura de Tecidos e Melhoramento Vegetal, \\ Departamento de Engenharia Agronômica, Universidade Federal de Sergipe, \\ São Cristóvão, SE, Brasil \\ ${ }^{3}$ Laboratório de Diversidade Genética e Melhoramento, \\ Departamento de Genética, Escola Superior de Agricultura "Luiz de Queiroz", \\ Universidade de São Paulo, Piracicaba, SP, Brasil \\ Corresponding author: M.I. Zucchi \\ E-mail: mizucchi@apta.sp.gov.br
}

Genet. Mol. Res. 14 (1): 971-974 (2015)

Received January 8, 2014

Accepted July 11, 2014

Published February 3, 2015

DOI http://dx.doi.org/10.4238/2015.February.3.4

\begin{abstract}
Microsatellite primers were developed and optimized for Lippia alba to characterize the L. alba germplasm bank of Universidade de São Paulo. A genomic library enabled the design of 9 microsatellite primers. Six of the 9 primers yielded polymorphic products, which defined 2 groups in the bank. The data provide support to characterize germplasm banks, genetic breeding programs for $L$. alba, and other genetic diversity studies and classifications of species in the genus Lippia.
\end{abstract}

Key words: Lippia alba; Microsatellite; Genetic diversity; Essential oils; Germplasm bank 


\section{INTRODUCTION}

Brazil has a wide diversity of medicinal plants that play an important role in traditional medicine. Lippia alba is a medicinal and aromatic plant of the Verbenaceae family, and it is spread around Central and South America. It is a shrub that produces essential oils with aromatizing, biological, and pharmacological properties. Essential oils from vegetal material of L. alba has potential uses in cosmetic industries, and it also has analgesic (Viana et al., 1998), anticonvulsant (Viana et al., 2000), sedative (Zétola et al., 2002), and antifungal (Shukla et al., 2009) activity. Accessions of L. alba may be defined in chemicals groups based on their major chemical components.

Information about the diversity and genetic structure in germplasm accessions is very important to allow the effective maintenance of different accessions with reduced costs (Gupta and Varshney, 2000). Microsatellites markers stand out despite the availability of other markers because they are multi-allelic and co-dominant, and they have a relatively high abundance and extensive genome coverage (Gupta and Varshney, 2000).

Despite these advantages, only 8 polymorphic microsatellite markers were previously published by Santos et al. (2012), indicating the necessity to increase the available set of these highly informative genetic markers for efficient management and improvement of $L$. alba germplasm resources. In this study, we describe 9 novel simple sequence repeat (SSR) markers for $L$. alba that were developed from a microsatellite-enriched library.

\section{MATERIAL AND METHODS}

The genomic DNA was extracted from young leaves of the $L$. alba accessions of the germplasm bank of Universidade de São Paulo. Leaves were collected from 90 accessions of the germplasm bank, instantly frozen with liquid nitrogen and stored at $-80^{\circ} \mathrm{C}$. The plant material was lyophilized, and DNA was extracted by the cetyltrimethylammonium bromide protocol described by Doyle and Doyle (1990). The DNA was quantified on a 1\% agarose gel stained with SYBR safe using different concentrations of lambda phage DNA.

A microsatellite-enriched library was constructed following adapted protocols from Billotte et al. (1999). Genomic DNA from one genotype of $L$. alba was digested with $A f a$ I (Invitrogen, Carlsbad, CA, USA) and enriched in microsatellite fragments using the $(\mathrm{CT})_{8}$ and $(\mathrm{GT})_{8}$ motifs. Microsatellite-enriched DNA fragments were ligated into the pGEM-T Easy Vector (Promega, Madison, WI, USA) and used to transform XL1-blue supercompetent cells. The positive clones were selected using the $\beta$-galactosidase gene and then were grown overnight with ampicillin. A total of 96 clones were sequenced in an ABI3700 automated sequencer (Applied Biosystems, Foster City, CA, USA) using a BigDye terminator cycle sequencing kit (Applied Biosystems).

The WebSat software (http://wsmartins.net/websat/) was used to identify the microsatellite-containing motifs. Nine primer pairs were designed for SSR-flanking regions using Primer3 (http://bioinfo.ut.ee/primer3-0.4.0/), and they were tested in 90 accessions of $L$. alba the germplasm bank.

Polymerase chain reaction (PCR) amplifications were performed in a $20-\mu \mathrm{L}$ volume consisting of $2.0 \mu \mathrm{L} 10 \mathrm{ng} / \mu \mathrm{L}$ DNA, $2.0 \mu \mathrm{L}$ 10X PCR buffer $(50 \mathrm{mM} \mathrm{KCl}, 10 \mathrm{mM}$ Tris-HCl, $\mathrm{pH}$ 8.9), $1.0 \mu \mathrm{L} 2.5 \mathrm{mM}$ dNTPs, $0.2 \mu \mathrm{L} 1 \mathrm{U}$ Taq DNA polymerase (Invitrogen), $1.6 \mu \mathrm{L} 25 \mathrm{mM}$ $\mathrm{MgCl}_{2}, 0.32 \mu \mathrm{L} 10 \mu \mathrm{M}$ forward primer synthesized with an M13 sequence on the 5'-end, 0.4 
$\mu \mathrm{L} 10 \mu \mathrm{M}$ reverse primer, $0.2 \mu \mathrm{L} 10 \mu \mathrm{M}$ IRDye-labeled M13 primer (LI-COR Biosciences, Lincoln, Nebraska, USA), and $10.88 \mu \mathrm{L} \mathrm{H}_{2} \mathrm{O}$.

The amplification program consisted of an initial denaturing step at $94^{\circ} \mathrm{C}$ for $5 \mathrm{~min}$; 10 cycles touchdown at $94^{\circ} \mathrm{C}$ for $40 \mathrm{~s}$ (denaturation), annealing temperature of each primer for $40 \mathrm{~s}\left(-1^{\circ} \mathrm{C}\right.$ per cycle), and $1 \mathrm{~min}$ at $72^{\circ} \mathrm{C}$ for fragment extension; 30 cycles at $94^{\circ} \mathrm{C}$ for 40 $\mathrm{s}, 40^{\circ} \mathrm{C}$ for $40 \mathrm{~s}$, and $72^{\circ} \mathrm{C}$ for $1 \mathrm{~min}$; a final extension cycle at $72^{\circ} \mathrm{C}$ for $10 \mathrm{~min}$; and finally $15^{\circ} \mathrm{C}$ forever.

The amplified fragments were electrophoresed on a LI-COR Model 4300 automated DNA sequencer (LI-COR Biosciences). Genotyping was performed by the Saga ${ }^{\mathrm{MX}}$ software (LI-COR Biosciences). The number of alleles and observed and expected heterozygosities were calculated using the MStools software (Park, 2001).

\section{RESULTS AND DISCUSSION}

Nine microsatellite primers were optimized and characterized for $L$. alba, and 6 were polymorphic (Table 1). The number of alleles per locus ranged from 1 to 7 alleles, with an average of 3.83 alleles per locus. All microsatellite loci were composed of dinucleotide repeats. The observed heterozygosity ranged from 0 to 0.494 (on average), and the expected heterozygosity ranged from 0.054 to 0.771 (on average).

Table 1. Microsatellite markers developed for Lippia alba.

\begin{tabular}{|c|c|c|c|c|c|c|c|c|}
\hline Locus & GenBank No. & Primer sequence $\left(5^{\prime}-3^{\prime}\right)$ & Repeat motif & $\mathrm{Ta}\left({ }^{\circ} \mathrm{C}\right)$ & Size range (bp) & $N_{\mathrm{A}}$ & $H_{\mathrm{O}}$ & $H_{\mathrm{E}}$ \\
\hline LAB05 & KF611774 & $\begin{array}{l}\text { F: TCCACCTCTTCTGCTTCACA } \\
\text { R: CAGTTCGTGGCATCTGTGTT }\end{array}$ & $(\mathrm{AC})_{19}$ & 50 & $123-141$ & 7 & 0.091 & 0.771 \\
\hline LAD03 & KF611775 & $\begin{array}{l}\text { F: CGACCTAAGACACACCTAAGCA } \\
\text { R: TGGAAATATGGGTTCACCTTG }\end{array}$ & $(\mathrm{CT})_{7}(\mathrm{AC})_{6}$ & 55 & $252-268$ & 2 & 0.056 & 0.054 \\
\hline LAE03 & KF611776 & $\begin{array}{l}\text { F: GCAGCTCCAAATCCAACAG } \\
\text { R: GTTGATTGCCAAAGCGTCTA }\end{array}$ & $(\mathrm{CA})_{9}$ & 56 & $254-260$ & 4 & 0.000 & 0.583 \\
\hline LAE09 & KF611777 & $\begin{array}{l}\text { F: GCATGAAATAATAAAATAAAAGACTCC } \\
\text { R: CCССТАAACCCCAAАСТCAT }\end{array}$ & $(\mathrm{AG})_{7}(\mathrm{GA})_{5}$ & 55 & 204 & 1 & 0.000 & 0.000 \\
\hline LAF04 & KF611778 & $\begin{array}{l}\text { F: GGCCTTGTGGTAAGATCCTG } \\
\text { R: ACCATGCTGGGTTTATGTCC }\end{array}$ & $(\mathrm{TA})_{5}(\mathrm{GT})_{10}$ & 55 & $165-177$ & 3 & 0.124 & 0.542 \\
\hline LAG04 & KF611779 & $\begin{array}{l}\text { F: TGGAATTGGCTAGGCATGAT } \\
\text { R: GGGTTGACCAAAAAGTCACAA }\end{array}$ & $(\mathrm{TG})_{8}$ & 55 & $206-216$ & 2 & 0.000 & 0.000 \\
\hline LAG05 & KF611780 & $\begin{array}{l}\text { F: CGATTCTGGAAAATCTGGGTA } \\
\text { R: TGTTCTTGATGTTCATAAACCCTA }\end{array}$ & $(\mathrm{CA})_{6}$ & 55 & 255 & 1 & 0.000 & 0.000 \\
\hline LAH06 & KF611781 & $\begin{array}{l}\text { F: TACACCACCACAGCAGCAC } \\
\text { R: ACAGGCTTTACGCACGAAGT }\end{array}$ & $(\mathrm{AG})_{8}$ & 55 & $174-180$ & 2 & 0.494 & 0.385 \\
\hline LAH09 & KF611782 & $\begin{array}{l}\text { F: CGTGTCTCGGGATATACGTG } \\
\text { R: CCTCACAAGAAAGCATGTGG }\end{array}$ & $(\mathrm{GT})_{7}$ & 55 & $252-266$ & 5 & 0.236 & 0.323 \\
\hline
\end{tabular}

$\mathrm{F}=$ forward; $\mathrm{R}=$ reverse; $\mathrm{Ta}=$ optimal annealing temperature; $N_{\mathrm{A}}=$ number of alleles; $H_{\mathrm{O}}=$ observed heterozygosity; $H_{\mathrm{E}}=$ expected heterozygosity. All values are based on 90 accessions belonging to the germplasm bank of the Universidade de São Paulo.

In this study, the expected heterozygosity was higher than the observed heterozygosity of $L$. alba because the genotypes were collected in many different locations and they were reproduced through stem cuttings. Therefore, the accessions are not in Hardy-Weinberg equilibrium.

The microsatellite markers that were developed in this study efficiently characterized the genetic diversity of $L$. alba germplasm accessions. These highly informative markers will 
provide support to manage the germplasm bank and will be useful for breeding programs for L. alba. These markers may be an important tool for distinguishing among species in the genus Lippia and may help identify quantitative trait loci, associations with agronomic and economic traits, and marker-assisted selection.

\section{ACKNOWLEDGMENTS}

Research supported by Coordenação de Aperfeiçoamento de Pessoal de Nível Superior and Conselho Nacional de Desenvolvimento Científico e Tecnológico.

\section{REFERENCES}

Billotte N, Lagoda PJL, Risterucci AM and Baurens FC (1999). Microsatellite-enriched libraries: applied methodology for the development of SSR markers in tropical crops. Fruits 54: 277-288.

Doyle JJ and Doyle JL (1990). Isolation of plant DNA from fresh tissue. Focus 12: 15.

Gupta PK and Varshney RK (2000). The development and use of microsatellite markers for genetic analysis and plant breeding with emphasis on bread wheat. Euphytica 113: 163-185.

Park S (2001). MStools V.3 (Excel Spreadsheet Toolkit for Data Conversion). Smurfit Institute of Genetics, Trinity College, Dublin.

Santos FR, Lima PF, Priolli RH, Siqueira WJ, et al. (2012). Isolation and characteristics of eight novel polymorphic microsatellite loci in Lippia alba (Verbenaceae). Am. J. Bot. 99: e301-e303.

Shukla R, Kumar A, Singh P and Dubey NK (2009). Efficacy of Lippia alba (Mill.) N.E. Brown essential oil and its monoterpene aldehyde constituents against fungi isolated from some edible legume seeds and aflatoxin B1 production. Int. J. Food Microbiol. 135: 165-170.

Viana GSB, do Vale TG, Rao VSN and Matos FJA (1998). Analgesic and antiinflammatory effects of two chemotypes of Lippia alba: a comparative study. Pharm. Biol. 36: 347-351.

Viana GSB, do Vale TG, Silva CM and Matos FJA (2000). Anticonvulsant activity of essential oils and active principles from chemotypes of Lippia alba (Mill.) N.E. Brown. Biol. Pharm. Bull. 23: 1314-1317.

Zétola M, De Lima TC, Sonaglio D, Gonzalez-Ortega G, et al. (2002). CNS activities of liquid and spray-dried extracts from Lippia alba-Verbenaceae (Brazilian false melissa). J. Ethnopharmacol. 82: 207-215. 